\title{
PARTISIPASI PETANI DAN KEBERHASILAN PROGRAM PENGEMBANGAN USAHA PANGAN MASYARAKAT (PUPM) DI KECAMATAN PALAS KABUPATEN LAMPUNG SELATAN
}

\author{
(The Participation of Farmers and The Success of Community Food Development Program (PUPM) \\ in Palas Subdistrict South Lampung Regency)
}

Resti Anggraini, Kordiyana K Rangga, Tubagus Hasanuddin

Jurusan Agribisnis, Fakultas Pertanian, Universitas Lampung, Jl. Prof. Dr. Soemantri Brojonegoro No.1 Bandar Lampung 35141, Telp. 082350732030, e-mail: restianggrainihabib@ gmail.com

\begin{abstract}
The purpose of this research is to know the level of farmers' participation, the factors associated with the level of farmers' participation and the relationship between the level of farmers' participation and the success of the program. Data of this research were collected in February-March 2018. The respondents are 66 rice farmers members of farmer groups joining the program who are chosen randomly The research is a survey and data are analyzed using Rank Spearman and descriptively. The results showed that the level of farmers' participation is in a low catergory. Factors related to the level of farmers ' participation in PUPM program are farmers' knowledge on the program, frequency of their participation in extension activities, and level of farmers' cosmopolitan character. There is a significant relationship between farmers ' participation and the success of PUPM program in Palas Subdistrict of South Lampung Regency.
\end{abstract}

Key words: farmer, participation, program, PUPM

\section{PENDAHULUAN}

Pangan merupakan kebutuhan dasar manusia yang paling utama. Pemenuhan kebutuhan pangan merupakan bagian dari hak asasi manusia yang dijamin dalam Undang-Undang Dasar No 18 Tahun 2012 tentang pangan. Harga komoditas pangan yang selalu berfluktuasi dapat merugikan petani sebagai produsen, masyarakat sebagai konsumen, dan berpotensi menimbulkan keresahan sosial lainnya (Sari 2010). Harga yang berfluktuasi tersebut mengakibatkan pemerintah Indonesia melalui Dinas Ketahanan Pangan membentuk program pelaksanaan kegiatan yang disebut "Pengembangan Usaha Pangan Masyarakat (PUPM)".

Pengembangan Usaha Pangan Masyarakat adalah kegiatan memberdayakan lembaga usaha pangan masyarakat (gapoktan, poktan, dan lembaga usaha masyarakat yang bergerak di bidang pangan), dan Industri/Produsen/Distributor Bahan Pangan dalam melayani Toko Tani Indonesia (TTI) untuk menjaga stabilisasi pasokan harga pangan. Toko Tani Indonesia adalah toko/warung/kios/pedagang komoditas pangan yang bermitra dengan Lembaga Usaha Pangan Masyarakat (LUPM) untuk menjual komoditas pangan hasil produksi petani sesuai harga yang wajar kepada konsumen dan pasokan dari mitra industri pangan. Sasaran dari program ini ialah petani, kelompok tani, dan gapoktan yang berusaha tani tanaman pangan khususnya padi.

Pelaksanaan Program Pengembangan Usaha Pangan Masyarakat tidak akan dapat berjalan tanpa adanya faktor-fakor pendukung salah satunya ialah partisipasi dari petani dan masyarakat. Menurut hasil penelitian Hasanuddin dan Muhammad (2012), keberhasilan pelaksanaan suatu program tidak terlepas dari beberapa faktor antara lain tingkat pengetahuan petani tentang program, peranan penyuluh pertanian, dukungan pemerintah, dan partisipasi petani dalam pelaksanaan program. Partisipasi adalah keikutsertaan masyarakat dalam suatu kegiatan, baik keterlibatan masyarakat dalam bentuk fisik ataupun nonfisik (Mardikanto 2010).

Menurut hasil penelitian Antika, Nikmatullah dan Prayitno (2017), partisipasi aktif dari setiap individu atau kelompok akan menentukan keberhasilan dari pelaksanaan suatu program. Oleh karena itu dalam hal ini partisipasi merupakan bagian terpenting dalam keberhasilan program, khusunya ialah Pogram PUPM di Kecamatan Palas Kabupaten Lampung Selatan. Berdasarkan uraian tersebut, maka tujuan dari penelitian ini adalah mengetahui tingkat partisipasi petani pada Program PUPM, mengetahui faktorfaktor yang berhubungan dengan tingkat partisipasi pada Program PUPM, dan mengetahui hubungan 
antara partisipasi petani dengan keberhasilan Program PUPM di Kecamatan Palas Kabupaten Lampung Selatan.

\section{METODE PENELITIAN}

Penelitian ini dilakukan di Kecamatan Palas, Kabupaten Lampung Selatan. Lokasi penelitian dipilih secara sengaja (purposive) dengan pertimbangan Kecamatan Palas merupakan kecamatan yang paling banyak melaksanakan Program PUPM dan merupakan salah satu sentra tanaman padi di Kabupaten Lampung Selatan. Pengambilan data dilakukan pada bulan Ferbuari sampai Maret 2018. Populasi pada penelitian ini adalah 190 orang anggota kelompok tani yang melaksanakan program PUPM, dari populasi tersebut jumlah sampel yang diperoleh sebanyak 66 responden yang ditetapkan berdasarkan rumus Yamane yang dikutip dari Ridwan dan Kuncoro (2008) dengan rumus sebagai berikut :

$\mathrm{n}=\frac{\mathrm{N}}{\mathrm{Nd}^{2}+1}$

Keterangan :

$\mathrm{n}=$ Jumlah sampel

$\mathrm{N}=$ Jumlah populasi

$\mathrm{d}=$ Presisi (ditetapkan 5\% dengan tingkat kepercayaan 95\%)

Metode pengambilan sampel penelitian ini ialah simple random sampling. Metode penelitian yang digunakan adalah metode survei. Data yang digunakan dalam penelitian adalah data primer dan data sekunder. Data primer ialah data yang diperoleh dari wawancara dengan menggunakan kuesioner, kemudian diintervalkan dengan metode MSI (Method Successive Interval). Data variabel yang diubah dengan menggunakan metode tersebut yaitu: 1) Variabel $X$ meliputi pengetahuan tentang Program PUPM, frekuensi komunikasi, motivasi, dan kekosmopolitan; 2) Variabel Y tingkat partisipasi petani; 3) Variabel Z keberhasilan program PUPM.

Variabel $\mathrm{X}$ yaitu faktor-faktor yang diduga berhubungan dengan tingkat partisipasi petani. Faktor-faktor tersebut ialah jumlah anggota keluarga petani, tingkat pengetahuan petani tentang Program PUPM, frekuensi komunikasi anggota, tingkat motivasi dan tingkat kekosmopolitan. Variabel Y merupakan tingkat partisipasi petani pada Program PUPM di Kecamatan Palas Kabupaten Lampung Selatan. Tingkat partisipasi dilihat dari tingkat partisipasi petani dalam perencanaan, tingkat partisipasi petani dalam pelaksanaaan program, tingkat partisipasi petani dalam pemantauan dan evaluasi, dan tingkat partisipasi petani dalam pemanfaatan hasil. Pengukuran variabel $\mathrm{X}$, dan $\mathrm{Y}$ menggunakan teknik skoring yang diklasifikasikan ke dalam tiga kelas yaitu rendah, sedang, dan tinggi, sedangkan untuk jumlah anggota keluarga petani diambil dari data riil di lapangan.

Variabel $\mathrm{Z}$ pada penelitian ini merupakan tingkat keberhasilan Program PUPM di Kecamatan Palas Kabupaten Lampung Selatan. Keberhasilan tersebut diukur dengan menggunakan tiga indikator yaitu masukan (input), keluaran (output), dan hasil (outcome). Pengukuran variabel $\mathrm{Z}$ juga menggunakan teknik skoring, dengan klasifikasi kurang berhasil, cukup berhasil, dan berhasil.

Analisis data pada penelitian ini menggunakan analisis deskriptif dan analisis statistik non parametrik uji korelasi Rank Spearman (Siegel 2011). Uji analisis korelasi Rank Spearman digunakan untuk mengetahui hubungan tingkat partisipasi petani dengan keberhasilan Program PUPM dan faktor-faktor yang berhubungan dengan tingkat partisipasi petani pada Program PUPM di Kecamatan Palas Kabupaten Lampung Selatan. Adapun rumus uji koefisien korelasi Rank Spearman (Siegel 2011) adalah sebagai berikut :

$\mathrm{rs}=1-\frac{6 \sum_{\mathrm{i}-1}^{\mathrm{n}} \mathrm{di}^{2}}{\mathrm{n}^{3}}$

\section{Keterangan :}

$r s=$ Penduga koefisien korelasi

$\mathrm{di}=$ Perbedaan setiap pasangan rank

$\mathrm{n}=$ Jumlah responden

Kaidah pengambilan keputusan adalah :

1. Jika nilai sig $\leq \alpha=0,05$ maka tolak Ho terima $\mathrm{Hi}$, berarti terdapat hubungan yang nyata antara kedua variabel yang diuji.

2. Jika nilai sig $>\alpha=0,05$ maka terima Ho tolak $\mathrm{Hi}$, berarti tidak terdapat hubungan yang nyata antara kedua variabel yang diuji.

\section{HASIL DAN PEMBAHASAN}

\section{Karakteristik Responden}

Jumlah responden secara keseluruhan sebanyak 66 orang petani di Kecamatan Palas Kabupaten Lampung Selatan. Responden penelitian ini ialah petani yang mengikuti Program PUPM di Kecamatan Palas Kabupaten Lampung Selatan. 
Mayoritas umur responden adalah 50 tahun. Tingkat pendidikan yang ditempuh oleh responden mayoritas adalah sekolah dasar (SD) yaitu 33 orang $(50,00 \%)$. Pendidikan formal yang diikuti responden akan memudahkan dalam menerima dan menyerap pengetahuan tentang Program PUPM maupun yang berkaitan dengan usaha tani mereka.. Mayoritas luas lahan garapan responden ialah 1,00 ha dengan klasifikasi sempit. Produksi padi yang dihasilkan oleh responden paling banyak masuk klasifikasi rendah dengan selang produksi 1,503,67 ton/ha yaitu sebanyak 29 orang $(43,94 \%)$. Pekerjaan sampingan yang dimiliki oleh responden yaitu pekerjaan sampingan yang masih berkaitan dengan pertanian 23 orang $(34,85 \%)$ seperti pekerjan sampingan peternak, petani kebun dan buruh tani, pekerjaan sampingan yang tidak berkaitan dengan pertanian 22 orang $(33,33 \%)$ seperti pekerjaan sampingan pedagang, kuli bangunan, ojek, dan lain-lain. Petani yang tidak memiliki pekerjaan sampingan terdapat 21 orang $(31,82 \%)$. Hal ini karena responden berfokus pada budidaya tanaman padi sawah sebagai pekerjaan utama untuk memenuhi kebutuhan hidup.

\section{Tingkat Partisipasi Petani pada Program PUPM}

Tingkatan partisipasi dibagi menjadi partisipasi dalam perencanaan, partisipasi dalam pelaksanaan kegiatan, partisipasi dalam pemantauan dan evaluasi, serta partisipasi dalam pemanfaatan hasilhasil pembangunan (Mardikanto 2011). Menurut Rangga dan Syarief (2017), tingkat partisipasi petani dalam perencanaan dilihat dari, intensitas pertemuan yang diikuti oleh petani, keinginan petani untuk mempersiapkan dan mengumpulkan data dari program tersebut, dan keinginan petani dalam memberikan masukan dan mengidentifikasi masalah yang terjadi pada program tersebut. Berdasarkan hasil lapang partisipasi petani di Kecamatan Palas Kabupaten Lampung Selatan dapat dilihat pada Tabel 1.

Tabel 1. Partisipasi Petani pada Program PUPM di Kecamatan Palas Kabupaten Lampung Selatan

\begin{tabular}{llcc}
\hline $\begin{array}{c}\text { Interval } \\
\text { (Skor) }\end{array}$ & Klasifikasi & $\begin{array}{c}\text { Jumlah } \\
\text { (orang) }\end{array}$ & $\begin{array}{c}\text { Persentase } \\
(\%)\end{array}$ \\
\hline $24,09-29,70$ & Rendah & 43 & 65,15 \\
$29,71-37,32$ & Sedang & 13 & 19,70 \\
$37,33-44,93$ & Tinggi & 10 & 15,15 \\
\hline Jumlah & & 66 & 100 \\
\hline \multicolumn{2}{l}{ Modus : 24,35 (Rendah) } & & \\
\hline
\end{tabular}

Tabel 1 menunjukkan bahwa, dari 66 responden sebanyak 10 responden $(15,15 \%)$ tingkat partisipasi petani pada Program PUPM berada pada klasifikasi tinggi, 13 responden $(19,70 \%)$ berada pada klasifikasi sedang, dan 43 responden $(65,15 \%)$ berada pada klasifikasi rendah. Hal ini karena pada kegiatan partisipasi dalam perencanaan dan partisipasi dalam pemantauan dan evaluasi termasuk ke dalam kategori rendah. Petani kurang ikut berkontribusi pada kegiatan awal perencanaan program. Kurangnya perhatian petani dalam mengawasi dan berkontribusi pada kegiatan evaluasi Program PUPM. Masih ada beberapa petani yang menjual hasil panen kepada tengkulak/pengepul, bahkan ada beberapa petani yang menjual hasil produksinya kepada truk atau fuso, yang nantinya hasil panen langsung diangkut dan dibawa untuk keluar daerah. Secara rinci partisipasi berdasarkan indikator tingkat partisipasi petani pada Program PUPM di Kecamatan Palas Kabupaten Lampung Selatan dapat dilihat pada Tabel 2, dengan uraian sebagai berikut :

Tingkat partisipasi petani dalam perencanaan berada pada klasifikasi rendah. Hal ini terjadi karena antusias petani yang kurang dalam mengikuti pertemuan rapat dengan gapoktan maupun rapat dengan poktan, petani juga kurang ikut terlibat dalam pemberian saran dan masukan pada perencanaan Program PUPM. Petani lebih memilih berada dirumah atau disawah dibandingkan mereka harus mengikuti pertemuan atau rapat, sehingga keputusan akhir perencanaan diserahkan kepada anggota tani yang lain atau jajaran pengurus. Menurut Rangga (2017), faktor menurunnya partisipasi seseorang dapat terjadi karena beberapa kegiatan yang dilakukan diawal sudah tidak rutin lagi dilaksanakan, dan adanya kegiatan lain atau kegiatan baru yang dilakukan sehingga menggangu proses partisipasi pada program tersebut.

Tingkat partisipasi petani dalam pelaksanaan program PUPM berada diklasifikasi tinggi. Petani mengikuti kegiatan rapat pelaksanaan Program, dan sosialisasi Program yang disampaikan oleh Penyuluh Pertanian. Sebagian petani ada yang mengikuti kegiatan penggilingan gabah hingga pada proses pendistribusian beras ke TTI. Partisipasi seseorang yang termasuk ke dalam kategori tinggi ialah adanya partisipasi yang aktif dalam kegiatan seperti membuat perencanaan kegiatan, adanya keterlibatan dalam pelaksanaan kegiatan, dan dapat merasakan manfaat dari berpartisipasi pada kegiatan tersebut (Rangga dkk. 2014). 
Tingkat partisipasi petani dalam pemantauan dan evaluasi berada diklasifikasi rendah. Hal ini terjadi karena kurangnya partisipasi petani pada proses pengawasan dan pemantauan program baik itu di tingkat gapoktan maupun di tingkat poktan. Rendahnya tingkat partisipasi petani dalam kegiatan rapat evaluasi bulanan yang dilakukan oleh LUPM/gapoktan dan kontribusi petani dalam memantau saat proses pembuatan Laporan Pertanggung Jawaban (LPJ). Hanya beberapa petani saja yang selalu mengikuti proses pemantauan dan evaluasi seperti jajaran pengurus, petani pendamping lapang, dan orang-orang yang berpengalaman dan berpengaruh baik ditingkat gapoktan / poktan.

Tingkat partisipasi petani dalam pemanfaatan hasil berada di klasifikasi tinggi. Berdasarkan hasil lapang banyak manfaat yang petani rasakan dari mengikuti Program PUPM. Gabah petani yang dibeli dengan harga tinggi akan meningkatkan pendapatan petani, petani sudah mengetahui target pasar produksinya, artinya petani tahu kemana mereka harus menjual hasil produksi. Program PUPM juga memotong rantai pasok yang panjang menjadi lebih singkat.

\section{Faktor-faktor yang Berhubungan dengan Tingkat Partisipasi petani pada Program PUPM}

Faktor-faktor yang berhubungan dengan tingkat partisipasi petani dianalisis dengan menggunakan uji korelasi Rank Spearman menggunakan aplikasi SPSS 22, yang dapat dilihat pada Tabel 3.

Tabel 2. Tingkat partisipasi petani berdasarkan indikator pada Program PUPM di Kecamatan Palas Kabupaten Lampung Selatan

\begin{tabular}{llcl}
\hline No & \multicolumn{1}{c}{ Partisipasi } & $\begin{array}{c}\text { Rata-rata } \\
\text { Skor }\end{array}$ & Klasifikasi \\
\hline 1. & $\begin{array}{l}\text { Partisipasi dalam } \\
\text { Perencanaan } \\
\text { Partisipasi dalam }\end{array}$ & 7,08 & Rendah \\
2. & $\begin{array}{l}\text { Pelaksanaan } \\
\text { Partisipasi dalam }\end{array}$ & 3,50 & Tinggi \\
3. & $\begin{array}{l}\text { Pemantauan dan } \\
\text { Evaluasi }\end{array}$ & Rendah \\
4. & $\begin{array}{l}\text { Partisipasi dalam } \\
\text { Pemanfaatan Hasil }\end{array}$ & 8,94 & Tinggi \\
\hline
\end{tabular}

a. Hubungan antara Jumlah Anggota Keluarga dengan Tingkat Partisipasi Petani

Hasil pengujian statistik antara jumlah anggota keluarga petani dengan tingkat partisipasi diperoleh nilai signifikansi sebesar 0,548. Nilai tersebut lebih besar dibanding dengan nilai $\alpha$ sebesar 0,05 atau pada tingkat kepercayaan 95 persen, artinya tidak terdapat berhubungan nyata dengan tingkat partisipasi petani pada Program PUPM di Kecamatan Palas Kabupaten Lampung Selatan. Hal tersebut terjadi karena terdapat pengelompokkan data pada klasifikasi sedang dengan rata-rata jumlah anggota keluarga petani yaitu 4 orang. Hal ini mengakibatkan data jumlah anggota keluarga petani tidak terdistribusi secara merata, sehingga data yang di dapat tidak bervariasi. Secara keseluruhan anggota keluarga petani seperti anak-anaknya masih banyak yang berada di bangku sekolah dan perguruan tinggi sehingga beberapa rumah tangga petani lebih memfokuskan kegiatannya untuk mengurus anakanak dan keluarganya. Hasil penelitian ini tidak sesuai dengan hasil penelitian Widyanti (2015) yang menyimpulkan bahwa jumlah anggota keluarga berhubungan dengan tingkat partisipasi petani pada suatu program.

b. Hubungan antara Tingkat Pengetahuan Petani Tentang Program PUPM dengan Tingkat Partisipasi Petani

Hasil pengujian statistik antara tingkat pengetahuan petani tentang program PUPM dengan tingkat partisipasi petani dapat dilihat pada Tabel 3. Berdasarkan uji statistik hubungan antara tingkat pengetahuan petani tentang Program PUPM dengan tingkat partisipasi petani diperoleh nilai signikansi sebesar 0,000 . Nilai tersebut lebih kecil dibanding dengan nilai $\alpha$ sebesar 0,05 atau pada tingkat kepercayaan 95 persen, artinya adanya hubungan yang nyata antara tingkat pengetahuan petani tentang program dengan tingkat partisipasi petani, Meningkatnya pengetahuan responden tentang Program PUPM akan membuat responden termotivasi dan mengetahui bahwa Program PUPM dapat memberikan manfaat bagi kehidupannya sesuai dengan tujuan awal dibentuknya program tersebut. Hasil penelitian ini sesuai dengan hasil penelitian Yama (2018) yang menyimpulkan bahwa tingkat pengetahuan tentang program berhubungan nyata dengan tingkat pasrtisipasi petani pada Program P2BN. 


\section{c. Hubungan antara Motivasi Petani dengan Tingkat Partisipasi Petani}

Hasil pengujian statistik hubungan antara motivasi petani dengan tingkat partisipasi petani pada Program PUPM pada Tabel 3, diperoleh hasil signikansi sebesar 0,112 nilai tersebut lebih besar dibanding dengan nilai $\alpha$ sebesar 0,05 atau pada tingkat kepercayaan 95 persen. Tidak terdapat hubungan yang nyata antara motivasi petani dengan tingkat partisipasi petani pada Program PUPM di Kecamatan Palas Kabupaten Lampung Selatan. Hal tersebut terjadi karena data motivasi petani tidak tersebar secara normal, adanya pengelompokkan data pada klasifikasi rendah dengan rata-rata motivasi petani yaitu 3,66. Tidak ada dorongan motivasi dari luar lingkungan petani, seperti jajaran pengurus dan pemerintah setempat, dalam mengikuti Program PUPM tersebut. Petani mengikuti Program PUPM hanya untuk meningkatkan pendapatan, tidak ada keinginan dari petani untuk mendapatkan ilmu dan pengetahuan baru, menambah relasi atau teman bagi kehidupan sosialnya. Hasil penelitian ini tidak sesuai dengan hasil penelitian Triana (2017) yang menyimpulkan bahwa terdapat hubungan yang nyata antara tingkat motivasi petani dengan tingkat partisipasi petani terhadap suatu program.

\section{d. Hubungan antara Frekuensi Komunikasi Petani dengan Tingkat Partisipasi Petani}

Hasil pengujian statistik antara frekuensi komunikasi petani dengan tingkat partisipasi petani dapat dilihat pada Tabel 3. Berdasarkan uji statistik hubungan antara frekuensi komunikasi petani dengan tingkat partisipasi petani pada Program PUPM diperoleh hasil signikansi sebesar 0,000 . Nilai tersebut lebih kecil dibanding dengan nilai $\alpha$ sebesar 0,05 atau pada tingkat kepercayaan 95 persen, artinya terdapat hubungan yang nyata antara frekuensi komunikasi petani dengan tingkat partisipasi petani pada Program PUPM di Kecamatan Palas Kabupaten Lampung Selatan. Adanya intensitas interaksi komunikasi yang sering terjadi antara petani dengan petani lain, petani dengan sesama anggota maupun petani dengan pengurus. Hasil penelitian ini sesuai dengan hasil penelitian Antika (2017) yang menyimpulkan bahwa terdapat hubungan yang nyata antara frekuensi/intensitas komunikasi dengan tingkat partisipasi petani disuatu program. e. Hubungan antara Tingkat Kekosmopolitan Petani dengan Tingkat Partisipasi Petani

Hasil pengujian statistik antara tingkat kekosmopolitan dengan tingkat partisipasi petani dapat dilihat pada Tabel 3. Hasil uji statistik hubungan antara tingkat kekosmopolitan dengan tingkat partisipasi petani pada Program PUPM diperoleh hasil signikansi sebesar 0,002 , nilai tersebut lebih kecil dengan nilai $\alpha$ sebesar 0,05 .

Terdapat hubungan yang nyata antara tingkat kekosmopolitan dengan tingkat partisipasi petani di Kecamatan Palas Kabupaten Lampung Selatan. Petani sudah mulai menggunakan media massa untuk memperoleh informasi terbaru baik terkait dengan pertanian maupun yang tidak. Beberapa petani sudah mulai menggunakan internet, dan aplikasi sosial media seperti what's up dll. Adanya kontak/interaksi petani dengan lingkungan luar guna mendapatkan pengetahuan dan ilmu-ilmu baru baik yang terkaitt dengan dunia pertanian maupun tidak. Hasil penelitian ini sesuai dengan penelitian Triana (2017) yang menyatakan bahwa terdapat hubungan yang nyata antara tingkat kekosmopolitan dengan tingkat partisipasi petani.

\section{Hubungan antara Partisipasi Petani dengan Keberhasilan Program PUPM}

Keberhasilan Program PUPM dilihat dari tiga indikator; (1) masukan (Input) merupakan tolak ukur kinerja maupun sumberdaya yang digunakan pada program PUPM di Kecamatan Palas Kabupaten Lampung Selatan, (2) keluaran (Output) merupakan hasil suatu aktifitas atau kegiatan dari pelaksanaan program PUPM di Kecamatan Palas Kabupaten Lampung Selatan, (3) hasil (Outcome) merupakan dampak dan maanfaat yang dirasakan dari mengikuti program PUPM di Kecamatan Palas Kabupaten Lampung Selatan. Berdasarkan hasil di lapang keberhasilan Program PUPM di Kecamatan Palas Kabupaten Lampung Selatan dapat dilihat pada Tabel 4. Berdasarkan Tabel 4 tersebut dapat ditarik kesimpulan bahwa Program PUPM secara keseluruhan berhasil dilaksanakan. Petani mendapatkan harga gabah yang tinggi sehingga dapat meningkatkan pendapatan, dan dengan adanya program ini keberadaan beras bagi konsumen telah terjamin. 
Tabel 3. Faktor-faktor yang berhubungan dengan tingkat partisipasi petani pada Program PUPM

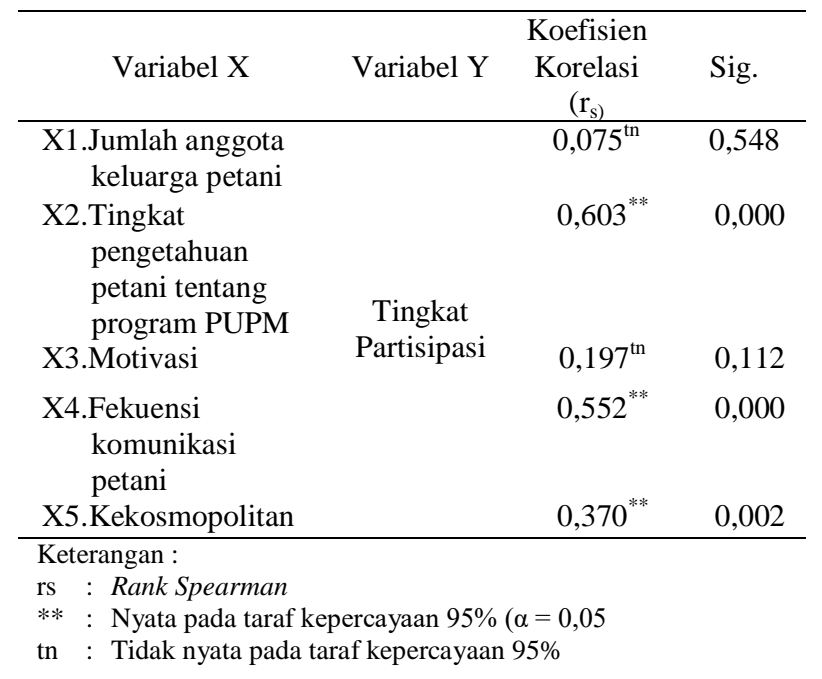

Tabel 4. Keberhasilan Program PUPM di Kecamatan Palas Kabupaten Lampung Selatan

\begin{tabular}{lccc}
\hline No. & Keberhasilan & $\begin{array}{c}\text { Rata-rata } \\
\text { Skor }\end{array}$ & Klasifikasi \\
\hline 1. & Input atau Masukan & 15,82 & Berhasil \\
2. & Ouput atau Keluaran & 9,02 & Berhasil \\
3. & Outcome atau Hasil & 13,78 & Berhasil \\
\hline
\end{tabular}

Hasil pengujian statistik hubungan antara partisipasi petani dengan keberhasilan Program PUPM, diperoleh nilai koefisien korelasi sebesar 0,665 dan nilai signifikansi 0,000. Nilai signifikansi tersebut lebih kecil dibanding dengan nilai $\alpha$ sebesar 0,05 atau pada tingkat kepercayaan 95 persen, artinya terdapat hubungan yang nyata antara tingkat partisipasi petani dengan keberhasilan Program PUPM. Hal ini membuktikan bahwa, partisipasi petani yang rendah tidak membuat program PUPM dikatakan tidak berhasil. Banyak manfaat dan dampak yang petani rasakan dari mengikuti Porgram PUPM tersebut terutama bagi kehidupan ekonominya, pendapatan petani meningkat, dan petani tidak lagi kebingungan untuk menjual hasil produksinya. Hasil penelitian ini sesuai dengan hasil penelitian Aria (2016) yang menyimpulkan bahwa terdapat hubungan yang nyata antara partisipasi petani dengan keberhasilan terhadap suatu program.

\section{KESIMPULAN}

Berdasarkan hasil penelitian tentang partisipasi petani dan keberhasilan Program Pengembangan Usaha Pangan Masyarakat (PUPM) di Kecamatan
Palas Kabupaten Lampung Selatan, maka dapat disimpulkan bahwa, tingkat partisipasi petani pada Program PUPM di Kecamatan Palas Kabupaten Lampung Selatan secara keseluruhan termasuk ke dalam klasifikasi rendah. Hal ini tampak dari tingkat partisipasi petani dalam perencanaan (rendah), partisipasi petani dalam pelaksanaan (tinggi), partisipasi dalam pemantauan dan evaluasi (rendah), dan partisipasi dalam pemanfaatan hasil (tinggi). Faktor-faktor yang berhubungan nyata dengat tingkat partisipasi petani pada Pogram PUPM ialah tingkat pengetahuan petani tentang Program PUPM, frekuensi komunikasi petani pada Program PUPM, dan kekosmopolitan petani, sedangkan faktor yang tidak berhubungan nyata dengan tingkat partisipasi petani pada Pogram PUPM ialah jumlah anggota keluarga dan motivasi. Terdapat Hubungan yang nyata antara partisipasi petani dengan keberhasilan Program PUPM di Kecamatan Palas Kabupaten Lampung Selatan.

\section{DAFTAR PUSTAKA}

Antika AY, Nikmatullah D, dan Prayitno RT. 2017. Tingkat partisipasi anggota P3A dalam Program Pengembangan Jaringan Irigasi (PJI) di Kelurahan Fajar Esuk Kecamatan Pringsewu Kabupaten Pringsewu. JIIA, 5(3): 335-343. http:// jurnal.fp.unila.ac.id/index .php/JIA/article/view/1647/1473. [11 April 2018].

Aria RA, Hasanuddin T, dan Prayitno RT. 2016. Peranan Penyuluh Pertanian Lapang (PPL) terhadap keberhasilan Program Pengembangan Usaha Agribisnis (PUAP) di Kecamatan Sungkai Selatan Kabupaten Lampung Utara. JIIA,4(4):430-436. http:// jurnal.fp.unila.ac.id/index.php/JIA/article/vie w/1526/1380. [11 April 2018].

Gitosaputro S dan Rangga KK. 2015. Pengembangan dan Pemberdayaan Masyarakat. Konsep Teori dan Aplikasinya di Era Otonomi Daerah. Diterbitkan oleh Lembaga Penelitian Universitas Lampung dengan Graha Ilmu. Yogyakarta.

Hasanuddin T dan Muhammad D. 2012. Tingkat keberhasilan Program Pengembangan Usaha Agribinis Pedesaan (PUAP) dalam meningkatkan pendapatan dan keberdayaan masyarakat petani di Pedesaan. Activita, 4(2); 151-167. http://repository.lppm.unila. ac.id/ 4239/. [11 April 2018].

Kuncoro EA dan Riduwan. 2008. Cara Menggunakan dan Memakai Analisis Jalur. Alfabeta. Bandung. 
Mardikanto T. 2010. Konsep Pemberdayaan Masyarakat. Tiga Serangkai. Surakarta.

Rangga KK. 2017. The Ability of The Community in The supporting The Local Resouce-Based Productive Effort in Food Self-Suffiencient Villages of Lampung Province. Proceeding of ISAE International Seminar Bandar Lampung, 10-12 Agustus 2017. Hal 765-770.

Rangga KK dan Syarief YA. 2017. Paddy farmer households' participation and food security level in special effort Program in Seputih Raman Sub-district of Central Lampung Regency. IOP Confrence Series: Earth and Enviromental Science, Vol 142: 1-5. Iopscience.iop.org/article/10.1088/1755-13 15/142/1/012060. [11 April 2018].

Rangga KK, Darsono, Anantanyu S, dan Wijaya M. 2014. The Participation of micro business affinity group members in the implementation of food self-suffiency action program in Lampung Province. Savap International. Academic Research International Vol 5(3). http://journals. savap. org.pk/vol5n3.html. [11 April 2018].

Sari DL. 2010. Analisis Spread Harga Gabah dan Beras Serta Integrasi Pasar dan Komoditas. Tesis. IPB. Bogor.
Siegel S. 2011. Statistik Non Parametrik Untuk Ilmu Sosial. PT Gramedia Pustaka Utama. Jakarta.

Triana RS, Rangga KK, dan Viantimala B. 2017. Partisipasi petani dalam program Upaya Khusus Peningkatan Produksi Padi, Jagung, dan Kedelai (UP2PJK) di Kecamatan Seputih Raman Kabupaten Lampung Tengah. JIIA, 5(4): 446-452. http://jurnal. fp.unila.ac.id/ index.php/JIA/article/view/1755/1558. [11 April 2018].

Republik Indonesia. 2012. Undang-Undang Dasar No 18. Tahun 2012 Tentang Ketahanan Pangan. Jakarta.

Widyanti E, Gitosaputro S, dan Yanfika H. 2015. Kebutuhan dan partisipasi masyarakat dalam Program Kemitraan dan Bina Lingkungan (PKBL) PTPN VII Unit Usaha Rejosari Kecamatan Natar Kabupaten Lampung Selatan. JIIA, 3(2): 195-202. http://jurnal.fp .unila.ac.id/index.php/JIA/article/view/1039 1944. [11 April 2018].

Yama IMT, Gitosaputro S, dan Hasanuddin T. 2018. Partisipasi petani padi dalam pelaksanaan Program Peningkatan Porduksi Beras Nasional (P2BN) di Kecamatan Mataram Lampung Tengah. JIIA, 6(1): 103109. http://jurnal.fp.unila.ac.id/index. php/ JIA/article/view/2505/2189. [11 April 2018]. 